International Research Journal of Management, IT \& Social Sciences
Available online at https://sloap.org/journals/index.php/irjmis/
Vol. 5 No. 4, July 2018, pages: $91 \sim 97$
ISSN: 2395-7492
https://doi.org/10.21744/irjmis.v5n4.274

\title{
Work and Knowledge of Mother Readiness in Exclusive Breastfeeding
}

Sri Mulyani a

Article history:

Received: 27 February 2018

Revised: 26 June 2018

Approved: 28 July 2018

Published: 31 July 2018

\section{Keywords:}

Work;

Mother;

Readiness;

Knowledge;

Exclusive breastfeeding;

\begin{abstract}
Knowledge of exclusive breastfeeding has been proven, through previous studies, as one of the factors that affect the readiness of pregnant mothers in exclusive breastfeeding. It is also widely reported about the job or profession mothers (especially those done outside the home) as factors inhibiting the implementation of exclusive breastfeeding. This study aims to examine the role of the moderator job as the relationship between knowledge of exclusive breastfeeding with maternal readiness in exclusive breastfeeding. Crosssectional study performed on pregnant women with first child, a sample of 139 respondents was taken to the criteria does not work (housewives) or working outdoors. Enclosed questionnaire was used to measure the knowledge and readiness of mothers in exclusive breastfeeding. The data analysis technique used is the linear regression model. The results showed that the significant effect of knowledge on the readiness of pregnant women at work $(\mathrm{R}=0.412$; $\mathrm{p}=0.002)$ but not significant in pregnant women who do not work $(\mathrm{R}=0.187$; $\mathrm{p}=0.086$ ). It can be concluded that the work has a role as moderator effect of exclusive breastfeeding knowledge about the readiness of pregnant mothers in exclusive breastfeeding.
\end{abstract}

2395-7492@ Copyright 2018. The Author. This is an open-access article under the CC BY-SA license (https://creativecommons.org/licenses/by-sa/4.0/) All rights reserved.

\section{Author correspondence:}

Sri Mulyani,

Faculty of Medicine, Sebelas Maret University

Email address: yaniartha@yahoo.com

\section{Introduction}

Working is an activity that should be done primarily to support life. Mother's job also expected to affect the knowledge and opportunity mothers in exclusive breastfeeding. Knowledge of respondents who are working is better when compared with the knowledge of respondents who did not work. Creswell, et.al. (2017), this is because mothers who are working outdoors (formal sector) have better access to information, especially information about exclusive breastfeeding. Working for women is often not an option, but for the husband, income is insufficient to meet household needs. Utami (2008) stated that work is not a reason to stop exclusive breastfeeding, although only three months maternity leave (1) Preoccupation with work, often make a mother forget and not exclusively breastfed her baby, Although the mother was taught how to maintain milk production, namely by pumping for working mothers and

${ }^{\text {a }}$ Faculty of Medicine, Sebelas Maret University, Indonesia 
frequently breastfeeding at night. It turned out that mothers who work, more quickly giving bottled milk with an excuse to get the baby used to suckle from a bottle when later left for work (2).

Ignorance of women will be a lot of things related to reproductive health will develop problems during pregnancy and after childbirth, therefore it is important for women to gain broad access to a variety of information relating to their reproductive health, as part of the fulfillment of women's reproductive rights. D'Ambruoso, et, al. (2009), women have a role and strategic position in the family and society as a pioneer, drivers, guards, and forts to protect her son also serves as an initiator for greater public awareness of it relating to the importance of exclusive breastfeeding for the quality of human resources in the future (Effendi \& Zamri, 2015; April).

Ohnishi, et al. (2005), found that mothers who had better literacy maternal health will be less likely to give birth to low birth weight, premature infants, infant mortality and failure in exclusive breastfeeding compared to those with lower literacy maternal health whereas, and this occurred after people perform sensing to a particular object. Knowledge domain is very important in shaping a person's actions (3).

Education will affect a person's education for responding to something that comes from outside. People who have a higher education will provide a more rational response than the uneducated. The level of education is a process where people are faced with the influence of elected and controlled environment, especially coming out of school so that they can obtain or has developed social skills and optimal individual ability. Education is divided into two, namely formal and nonformal education. Hancock, T. (2001), formal education is education that is structured to have level/level in a period of a certain time, lasted from elementary school through to university and is included in addition to academic studies public as well as various programs in particular and institutions for technical training and professional, while the non-formal education is an education generally non-formal training in specific aspects such as primary education or special training skills (4). Mardikanto, T. (2010), the level of education is one of the internal factors that affect a person in lifestyle, especially in motivating for the attitude to participate in health development. The higher a person's education level, the more easily interpret the information thus creating a good thing, otherwise, less education would hamper one's interpretation of information objects newly introduced (4).

Readiness mothers in exclusive breastfeeding are the attitude and behavior of the mother is a form of maturity mother to decide and prepared before exclusive breastfeeding. The shape of a person's maturity is influenced by the level of development of the individual. According to Huncock (2009), the term means the development of a series of progressive changes that occur as a result of the process of maturation or maturation and experience (5). This means that the development of not only the addition of height or increased ability, but rather a process of integration of many complex structures and functions (Mulyana, E., \& Killat, 2002; July).

Welcomes the readiness of pregnancy are reflected in the readiness and emotional response in accepting the pregnancy. A woman looking at pregnancy as a natural result of the marriage relationship, both intended and unintended. Most of the other women received a pregnancy as a whim of nature, and even in some women, including many teens, the pregnancy is the result of sexual experimentation without the use of contraceptive (Soeharsono \& Mandang; 2008, Suwitri \& Sidiartha; 2018).

\section{Research Methods}

Cross-sectional study: Performed on pregnant women with a first child who lives in the city of Surakarta. Sampling was carried out with the criteria of whether the pregnant women did not work (housewives) or working outdoors (6),(7),(8). Pregnant women who are working where the job does not require outdoors was not used as a sample. With these criteria taken a sample of 139 respondents. Knowledge and preparedness in exclusive breastfeeding were measured by a questionnaire enclosed. Knowledge of the subject is measured by four indicators, namely the sense of exclusive breastfeeding knowledge, understanding IMD, the benefits of exclusive breastfeeding and feeding techniques. Readiness is measured by five indicators of maternal health readiness, the psychological readiness of the mother, the mother's breast readiness, nutrition / maternal nutrition and infant health preparedness. Each indicator is expressed in some of the items the question that has been validated both in terms of language or sentence structure (content validity) as well as from the side of the construct. All constructs (variables) also has a high reliability (Cronbach alpha > 0.9). To analyze the moderator variables, the sample was divided into two categories based on the moderator variables (who is working and does not work). Data in each group were analyzed using linear regression models were then compared the results. Data processing was performed using SPSS for Windows version 13. Statistical testing is done with a significance level of $5 \%$. 


\section{Results and Analysis}

Respondents are pregnant women aged 16 to 40 years with the highest proportion in the age category of 21-25 years $(64.0 \%)$. Most are high school graduates (54.7\%) and newly married less than 2 years (68.3\%). Comparison of the proportion of working mothers with who is did not was $38.8 \%$ vs. $61.2 \%$. Description of the characteristics of respondents can be seen in Table 1 .

Table 1

Characteristics description respondents

\begin{tabular}{ccc}
\hline \multicolumn{1}{c}{ Characteristics } & F & $\%$ \\
\hline Age & & \\
16-20 years old & 10 & 7.2 \\
21-25 years old & 89 & 64,0 \\
26-30 years old & 35 & 25.2 \\
31-35 years old & 3 & 2.2 \\
36-40 years old & 2 & 1.4 \\
Education & & \\
elementary & 1 & 0.7 \\
Junior & 20 & 14.4 \\
High School & 76 & 54.7 \\
University & 42 & 30.2 \\
Marriage Lenght & & \\
<2 years & 95 & 68.3 \\
2-5 & 90 & 28,8 \\
years $>5$ years & 40 & 2.9 \\
Working & 4 & \\
Yes & & 38.8 \\
No & 54 & 61.2 \\
\hline
\end{tabular}

The concept of moderation when the moderator dichotomous variable (nominal two categories) are the independent variables on the dependent variable is significant at the objects that are in category one and is not a significant influence on objects that are in another category. Calculation of the relation of knowledge to the readiness of pregnant mothers in exclusive breastfeeding in the two groups of samples with linear regression techniques (see Table 2) shows the results support the concept. In the group of working mothers, there is a significant effect on the readiness of knowledge $(R=0.412 ; p=0.002)$. In the group of mothers who do not work, no significant effect on the readiness of knowledge $(\mathrm{R}=0.187 ; \mathrm{p}=0.086)$. It can be concluded that the job has a role as a moderator of the influence of maternal knowledge about breastfeeding exclusively on its readiness for exclusive breastfeeding.

Table 2

Calculation results between knowledge and the readiness of exclusive breastfeeding

\begin{tabular}{ccccc}
\hline Group & Work & $\mathrm{N}$ & $\mathrm{R}$ & $\mathrm{p}$ \\
\hline 1 & Working & 54 & 0.412 & $0.002 *$ \\
2 & Do Not Working & 85 & 0.187 & 0.086 \\
\hline Note: & $* \mathrm{p}<0.05$ & & &
\end{tabular}

Mulyani, Mulyani, S. (2018). Work and knowledge of mother readiness in exclusive breastfeeding. International Research Journal of Management, IT and Social Sciences, 5(4), 91-97. https://doi.org/10.21744/irjmis.v5n4.274 


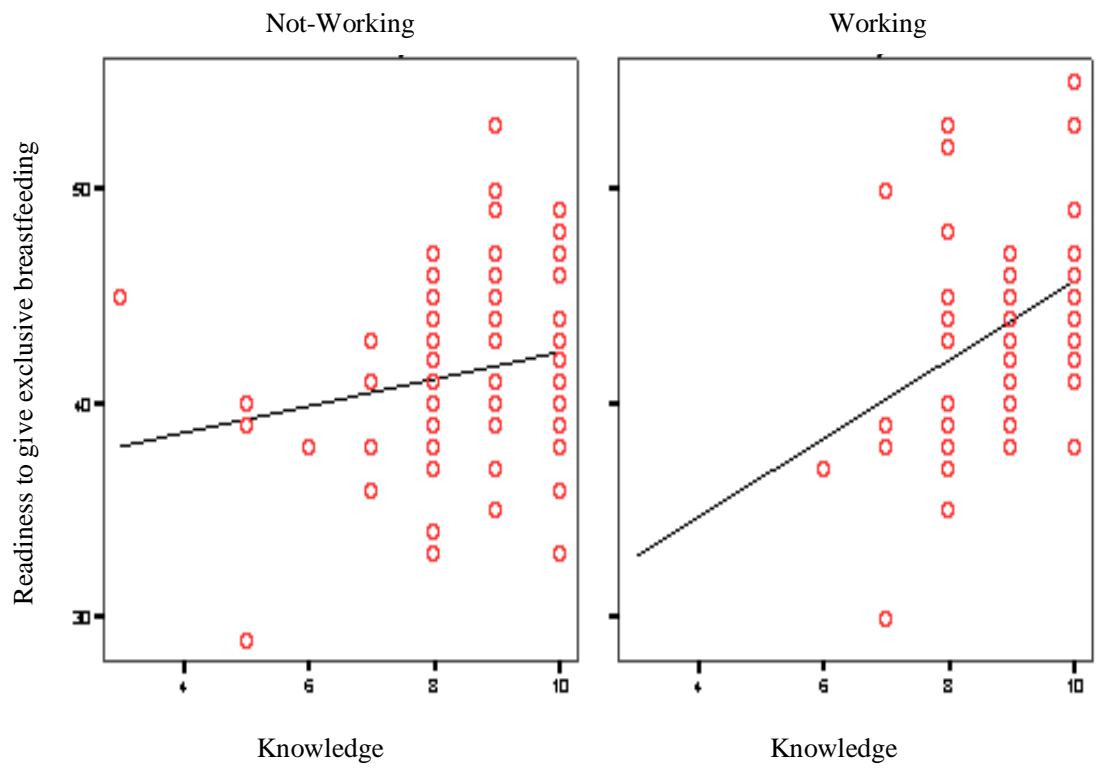

Linear Regression

Figure 1. Comparison of scatterplot knowledge relations with readiness in exclusive breastfeeding on working mother and housewife mother

Explanation of the job moderating effect can be seen by looking at the pattern of the scatterplot in Figure 1. Women who do not work (see the scatterplot left), high knowledge does not always lead to a high readiness as well. Besides, a low knowledge does not always lead to a low readiness anyway. Can be seen there are some pregnant women with a high knowledge, in fact, have a low readiness and also there are some pregnant women with low knowledge, in fact, have a high readiness. This shows that pregnant women who do not work (housewives), knowledge is not a significant factor in the readiness of exclusive breastfeeding.

In women who work (see the scatterplot right), it is hardly found mothers with low knowledge about exclusive breastfeeding. Despite that clear pattern can be seen how the work of pregnant women with a higher knowledge will have a higher readiness anyway. Likewise, pregnant women working with a lower knowledge will have a lower readiness anyway. This shows that pregnant women who work outside the home, knowledge is one of the significant factors for the readiness of exclusive breastfeeding.

The results of this study describe evidence of how the profession or occupation (especially outdoors) can moderate the effects of maternal knowledge about breastfeeding exclusively on its readiness for exclusive breastfeeding. For pregnant women who do not work, knowledge is not a significant factor in its readiness to exclusive breastfeeding. Therefore, since the time of pregnancy and later when in lactation, the mother spends more time at home and not much preoccupied with work activities, the readiness in exclusive breastfeeding will be more influenced by family support and also support health workers. The socio-cultural influence that often arises primarily through persuasion or even absolute parental interference also will influence the readiness of pregnant mothers in exclusive breastfeeding (9).

Work is generally a little more certainly hinder the implementation of exclusive breastfeeding. Pregnant women who are working would have predicted the difficulties that will be encountered later on when it should be breastfeeding while working. The government has already instructed and called for each agency or institution to provide opportunities and facilities for the employees who will provide exclusive breastfeeding for the baby. Despite that opportunity and the facility will only be put to good use by mothers who have a good understanding of exclusive breastfeeding, especially regarding the proper feeding techniques. This is what the role of moderating job. Pregnant women who work will be better prepared to provide exclusive breastfeeding if she has a high knowledge about exclusive breastfeeding. This is because he already knows what to do to be able to exclusively breastfeed their children even though the need while working. Instead of pregnant women who work with low knowledge on exclusive breastfeeding are most likely to be ill-equipped exclusively breastfed. These results imply that socialization, counseling, and teaching about 
exclusive breastfeeding need to be done on all pregnant women and further emphasized against pregnant women who have a job or a profession outside the home.

\section{Conclusion}

This study concludes their job role as moderator effect of exclusive breastfeeding knowledge about the readiness of pregnant mothers in exclusive breastfeeding. In pregnant women who do not work, knowledge is not a significant factor in the readiness of pregnant mothers in exclusive breastfeeding. As for pregnant women at work, knowledge is a significant factor in the readiness of pregnant mothers in exclusive breastfeeding

Conflict of interest statement and funding sources

The author declared that she has no competing interest. The study was financed by personal funding.

Statement of authorship

The author has a responsibility for the conception and design of the study. The author has approved the final article.

Acknowledgments

The author would like to thank the editor of IRJMIS for their support, valuable time, and advice.

Mulyani, Mulyani, S. (2018). Work and knowledge of mother readiness in exclusive breastfeeding. International Research Journal of Management, IT and Social Sciences, 5(4), 91-97. https://doi.org/10.21744/irjmis.v5n4.274 


\section{References}

Creswell, J. W., \& Creswell, J. D. (2017). Research design: Qualitative, quantitative, and mixed methods approaches. Sage publications.

D’Ambruoso, L., Achadi, E., Adisasmita, A., Izati, Y., Makowiecka, K., \& Hussein, J. (2009). Assessing quality of care provided by Indonesian village midwives with a confidential enquiry. Midwifery, 25(5), 528-539.

Effendi, M., \& Zamri, K. A. (2015, April). Psychometric assessment on Adversity Quotient instrument (IKBAR) among polytechnic students using Rasch model. In In the Proceedings of the International Conference on Education and Educational Technologies (EET), Barcelona, Spain: Institute for Natural Sciences and Engineering (pp. 52-7).

Hancock, T. (2001). People, partnerships and human progress: building community capital. Health Promotion International, 16(3), 275-280.

Mardikanto, T. (2010). Models of Community Empowerment.

Mulyana, E., \& Killat, U. (2002, July). An alternative genetic algorithm to optimize OSPF weights. In Internet Traffic Engineering and Traffic Management, 15th ITC Specialist Seminar (pp. 186-192).

Ohnishi, M., Nakamura, K., \& Takano, T. (2005). Improvement in maternal health literacy among pregnant women who did not complete compulsory education: policy implications for community care services. Health Policy, 72(2), 157-164.

Soeharsono, R. P., \& Mandang, T. (2008). Self-excited vibration phenomenon on vibrating subsoiler caused by natural excitation of varied cutting foree. Jurnal Teknik Mesin, 10(1), 46-51.

Suwitri, N. P. E., \& Sidiartha, I. G. L. (2018). Omega-6 and Omega-3 Fatty Acid Content and Ratio of Commercial Complementary Foods. International Journal of Health Sciences (IJHS), 2(1), 21-28.

Utami, R. (2008). Inisiasi menyusu dini plus ASI eksklusif. Jakarta: Pustaka Bunda, 2-31. 


\section{Biography of Author}

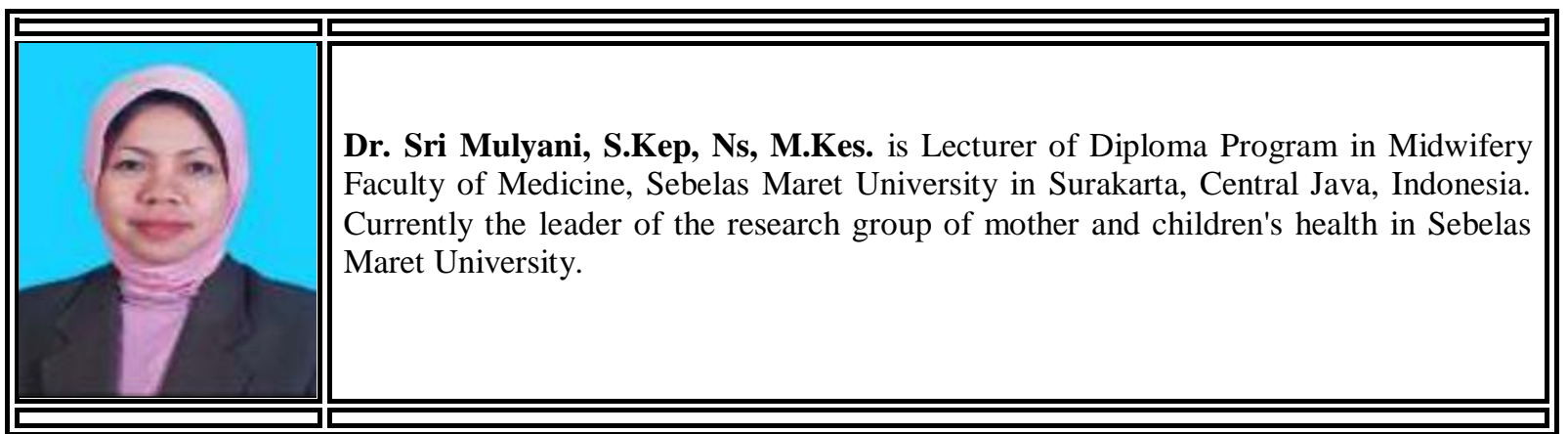

Mulyani, Mulyani, S. (2018). Work and knowledge of mother readiness in exclusive breastfeeding. International Research Journal of Management, IT and Social Sciences, 5(4), 91-97. https://doi.org/10.21744/irjmis.v5n4.274 